\title{
PENERAPAN HAZARD ANALYSIS CRITICAL CONTROL POINT (HACCP) TUNA
} (Thunnus sp.) LOIN BEKU DI PT. TRIDAYA ERAMINA BAHARI

\section{IMPLEMENTATION OF HAZARD ANALYSIS CRITICAL CONTROL POINT (HACCP) FROZEN TUNA (Thunnus sp.) LOIN IN PT. TRIDAYA ERAMINA BAHARI}

\author{
Nirmala Efri Hasibuan ${ }^{1 *}$, Aulia Azka1 ${ }^{1}$ Anisa Rohaini ${ }^{1}$ \\ ${ }_{1}^{1}$ Politeknik Kelautan dan Perikanan Dumai, Jl. Wan Amir, No.1, Kelurahan Pangkalan Sesai, \\ Kecamatan Dumai Barat, Kota Dumai, Provinsi Riau, Indonesia \\ *Korespondensi: nirmala.efrihsb@gmail.com (NE Hasibuan) \\ Diterima 26 Agustus 2020 - Disetujui 30 September 2020
}

\begin{abstract}
ABSTRAK. PT. Tridaya Eramina Bahari adalah salah satu perusahaan perikanan produsen tuna loin beku di Jakarta. Standar yang ditetapkan untuk menjamin sistem keamanan pangan yaitu HACCP (Hazard Analysis Critical Control Point) harus dipenuhi oleh perusahaan untuk menjamin mutu produk. Tujuan dari penelitian ini yaitu untuk mengetahui penerapan HACCP pada pengolahan tuna loin beku di PT. Tridaya Eramina Bahari. Penelitian ini bersifat deskriptif dengan metode yang digunakan yaitu metode survei dengan menggunakan kuisioner dari responden. Berdasarkan 12 langkah penerapan HACCP di PT. Tridaya Eramina Bahari meliputi pembentukan tim HACCP, deskripsi produk, identifikasi penggunaan, penyusunan diagram alir proses, pemeriksaan diagram alir proses, analisa bahaya, penetapan Critical Control Point (CCP), penetapan batas kritis, penetapan prosedur monitoring, tindakan koreksi, tindakan verifikasi, serta penetapan dan dokumentasi sudah diterapkan, namun ada tiga tahapan proses yang perlu ditingkatkan keamanan pangannya. Hasil evaluasi penerapan HACCP di PT. Tridaya Eramina Bahari menunjukkan bahwa CCP yaitu pada tahap penerimaan bahan baku, pengemasan dan pelabelan, serta pendeteksian logam.
\end{abstract}

KATA KUNCI: HACCP, Titik Kendali Kritis (CCP), Tuna Loin Beku, Pembekuan

ABSTRACT. PT. Tridaya Eramina Bahari is a fisheries industry that produces frozen tuna loin in Jakarta. Standards that set to guarantee a food safety system, namely HACCP (Hazard Analysis Critical Control Point) must be fulfilled by the company to ensure product quality. The purpose of the study was to evaluate the application of HACCP in Frozen loin tuna processing at PT. Tridaya Eramina Bahari. This research was descriptive with the method used was the survey method using a questionnaire of the selected respondents. Based on the 12 steps of implementing HACCP at PT. Tridaya Eramina Bahari including the HACCP team formation, product description, using identification, preparation of process flow diagram, checking process flow diagrams, hazard analysis, establishing Critical Control Points (CCP), determining critical limits, establishing monitoring procedures, corrective action, verification action, and establishing and documentation has been implemented, but there are three step that need to be improved in food safety sistem. HACCP evaluation results at PT. Tridaya Eramina Bahari shows that CCP was receiving raw materials step, packaging and labeling, as well as metal detection.

KEYWORDS: HACCP, Critical Control Point (CCP), Frozen Tuna Loin, Freezing

\section{Pendahuluan}

Indonesia memiliki potensi sumber daya perikanan yang sangat besar terutama dari kelompok Ikan pelagis besar salah satunya ikan tuna. Volume produksi ikan tuna terus meningkat dari tahun 2000 hingga tahun 2015 (Firdaus 2018). Ikan tuna merupakan salah satu komoditas ekspor terbesar di 
Indonesia. Indonesia juga merupakan negara kontributor produksi terbesar diantara 32 negara anggota Indian Ocean Tuna Commission (IOTC) dengan rata-rata produksi tahun 2009 - 2012 sebesar 356.862 ton per tahun (KKP, 2015). Tingginya volume ekspor ikan tuna juga tidak terlepas dari permasalahan global bahaya keamanan pangan. Penolakan yang sering terjadi dari negara-negara importir karena masalah tingginya kadar histamin. Penolakan ini terjadi karena permintaan konsumen terhadap jaminan keamanan pangan serta kelayakan dan standarisasi pengujian akan produk yang dikonsumsi. Emborg et al. (2005), menyatakan bahwa histamin menjadi masalah besar di dunia, dimana lebih dari 50\% semua kasus keracunan di Amerika dan Inggris karena faktor ini.

Penerapan sistem mutu manajemen keamanan pangan HACCP sudah seharusnya dilaksanakan dengan baik. Prayitno dan Sigit (2019) meyatakan bahwa pendekatan melalui HACCP membantu perencanaan dan operasional dalam kegiatan produksi pangan terutama dalam keamanan pangan dan kesehatan yang memfokuskan pada berbagai bahaya (hazard) secara langsung. Saat ini banyak organisasi yang merujuk HACCP sebagai sistem analisis dan pengendalian resiko kesehatan yang terkait produk pangan.

PT. Tridaya Eramina Bahari merupakan perusahaan yang bergerak di bidang pengolahan hasil perikanan, salah satunya adalah jenis ikan tuna beku dan olahannya. Produk yang dihasilkan telah di ekspor ke berbagai negara. Produk yang telah beredar luas harus dipastikan memenuhi standar pangan yang ada. Standar yang ditetapkan untuk menjamin sistem keamanan pangan yaitu HACCP (Hazard Analysis Critical Control Point) yang harus dipenuhi oleh perusahaan agar proses produksi dapat dikendalikan dan menghasilkan produk aman dan berkualitas. Penelitian ini bertujuan untuk mengetahui dan mengevaluasi penerapan sistem HACCP pada tuna loin beku di PT. Tridaya Eramina Bahari dan mendapatkan informasi titik-titik bahaya pada bahan baku dan tahapan proses tuna loin beku.

\section{Bahan dan Metode}

\subsection{Waktu dan Lokasi Penelitian}

Penelitian ini dilakukan di PT. Tridaya Eramina Bahari Jl. Muara Baru Ujung Blok K No. 3, Kecamatan Penjaringan, Jakarta Utara. Penelitian ini merupakan penelitian kualititatif dengan menggunakan sumber obyek untuk diwawancarai guna memperoleh data. Bahan yang digunakan dalam penelitian ini yaitu alat tulis dan lember kuisioner.

\subsection{Metode Penelitian}

Metode yang digunakan dalam penelitian ini adalah metode survei dan disajikan secara deskriptif dengan menggambarkan dan menjelaskan kajian teori yang sifatnya konseptual berdasarkan pustaka Penelitian dilakukan dengan cara mengikuti langsung alur proses penanganan tuna loin beku mulai dari tahap awal produksi hingga produk akhir. Data yang diperoleh terdiri atau data primer dan data sekunder, dan di amati menggunakan tabel pohon keputusan dan data deskripsi. Data primer diperoleh dengan melakukan wawancara dan observasi langsung di lapangan, analisis bahaya, identifikasi titik kendali kritis, pengawasan terhadap titik kendali kritis.

\section{Hasil dan Pembahasan}

\subsection{Penerapan HACCP pada Pembekuan Tuna Loin Di PT. Tridaya Eramina Bahari}

PT. Tridaya Eramina Bahari merupakan salah satu perusahaan perikanan yang telah berdiri sejak tahun 1994. Pt. Tridaya Eramina Bahari saat ini mengekspor berbagai produk perikanan beku seperti tuna loin beku. Proses pembekuan tuna loin di PT. Tridaya Eramina Bahari terdiri dari 16 tahapan proses dari awal hingga akhir. Setiap tahapan proses harus dilakukan sesuai langkah kerja yang berurutan agar tidak terjadinya kontaminasi silang. Proses produksi tuna loin beku di PT. Tridaya Eramina Bahari adalah penerimaan bahan baku, sortasi, penimbangan I, penyimpanan beku, 
pemotongan tuna, perapihan dan pembuangan kulit, penimbangan $\mathrm{II}$, pencucian, penyusunan, pembekuan, penggelasan (glazing), penimbangan III, pengemasan dan pelabelan, pemeriksaan logam, penyimpanan beku (cold storage), pemuatan dan pengiriman.

Penerapan HACCP (Hazard Analysis Critical Control Point) di PT. Tridaya Eramina Bahari sebagai salah satu sistem keamanan pangan untuk menjamin kualitas produk tuna loin beku yang dihasilkan untuk ekspor. HACCP merupakan suatu sistem keamanan pangan yang berperan mengidentifikasi, mengevaluasi dan mengontrol bahaya dalam pangan. Bahaya dalam pangan dapat berupa bahaya biologi, kimia dan fisik (Soman, 2016). HACCP berperan sebagai sistem pendekatan dalam pengawasan pangan secara resmi dan untuk menetapkan standar keamanan pangan dalam perdagangan pangan internasional (Pal, 2016). Selain itu, HACCP juga berfungsi sebagai alat manajemen bisnis dan memberikan pengaruh positif pada masyarakat karena memastikan pasokan makanan aman dikonsumsi dan kinerja ekspor perusahaan pangan lebih terjamin (Szyrocha, 2020). Penerapan HACCP di PT. Tridaya Eramina Bahari berdasarkan 12 langkah HACCP sebagai berikut:

\section{Pembentukan Tim HACCP}

Tahapan awal dalam penerapan HACCP adalah pembentukan tim. Tim HACCP di PT. Tridaya Eramina Bahari terdiri dari karyawan dari berbagai departemen dalam divisi pengolahan, laboratorium dan penyimpanan. Hal ini sesuai dengan pernyataan Prayitno dan Sigit (2019) bahwa tim HACCP memiliki latar belakang pendidikan yang berbeda yang memiliki tugas dalam pengawasan mutu, penjaminan mutu, pengolahan pangan, GMP, mikrobiologi pangan, penanganan proses dan pemeliharaan sarana dan prasarana (peralatan), dan melakukan langkah - langkah HACCP. Susunan tim HACCP PT. Tridaya Eramina Bahari ditunjukkan pada tabel 1.

\section{Tabel 1. Tim HACCP di PT. Tridaya Eramina Bahari}

\begin{tabular}{|c|c|c|}
\hline No & Jabatan & Tanggung Jawab \\
\hline 1 & Director & $\begin{array}{l}\text { Memiliki dan melaksanakan wewenang serta melakukan fungsi } \\
\text { manajemen perusahaan dan bekerja sama dengan bagian-bagian } \\
\text { yang ada dibawahnya. }\end{array}$ \\
\hline 2 & General Manager & $\begin{array}{l}\text { Memberikan kewenangan akan design, dan implementasi sistem } \\
\text { kontrol kepada QA Manager. }\end{array}$ \\
\hline 3 & Purchasing & $\begin{array}{l}\text { 1. Mengadakan pembelian ikan yang memenuhi standar mutu } \\
\text { ekspor } \\
\text { 2. Melakukan kerja sama dengan divisi lain terutama bagian quality } \\
\text { control dan penerimaan serta ABF/storaging } \\
\text { 3. Membuat laporan pembelian yang akurat }\end{array}$ \\
\hline 4 & Production & $\begin{array}{l}\text { 1. Menjamin bahwa semua karyawan di departemennya terlatih } \\
\text { dan memahami sistem keamanan pangan } \\
\text { 2. Menjamin bahwa semua produk yang dihasilkan telah sesuai } \\
\text { dengan standar peryaratan mutu dan keamanan pangan } \\
\text { 3. Menjamin proses yang berlangsung di area produksi telah sesuai } \\
\text { dengan GMP, SOP dan SSOP yang telah ditetapkan }\end{array}$ \\
\hline 5 & Quality Assurance & $\begin{array}{l}\text { Ketua Tim HACCP, memastikan syarat-syarat implementasi } \\
\text { HACCP terpelihara dan terimplementasi dengan baik. }\end{array}$ \\
\hline 6 & Quality Control & $\begin{array}{l}\text { 1. Menjalankan wewenang serta tugas } Q C \text { yang mencakup } \\
\text { pengawasan terhadap semua mutu produk } \\
\text { 2. Melakukan pengujian terhadap mutu produk yang mencakup } \\
\text { kualitas, ukuran, dan bobot. } \\
\text { 3. Melakukan analisi terhadap kualitas produk dalam rangka } \\
\text { peningkatan mutu produk } \\
\text { 4. Mengawasi bagian-bagian yang ada didalamnya }\end{array}$ \\
\hline
\end{tabular}


Aurelia Journal, Vol. 2 (1): 53-62

\begin{tabular}{lll}
\hline No & Jabatan & \multicolumn{1}{c}{ Tanggung Jawab } \\
\hline 7 & Mechanic & $\begin{array}{l}\text { Memastikan kondisi mesin produksi dalam konidisi yang baik } \\
\text { selama proses produksi }\end{array}$ \\
\hline
\end{tabular}

\section{Deskripsi Produk}

Deskripsi produk bertujuan untuk mengetahui komposisi utama produk, karakteristik produk, pengemasan, struktur kimia/fisik, informasi keamanan, cara penyimpanan, perlakuan pengolahan, petunjuk penggunaan dan metode distribusi produk. Deskripsi produk termasuk bagian penting yang dapat membantu konsumen mengetahui informasi tentang produk dan menghindari potensi bahaya pada produk akhir. Potensi bahaya dapat dikendalikan dengan tindakan pencegahan dalam keseluruhan proses (Oo, 2019). Deskripsi produk tuna loin beku di PT. Tridaya Eramina Bahari terdapat pada Tabel 2.

Tabel 2. Deskripsi Produk Tuna Loin Beku di PT. Tridaya Eramina Bahari

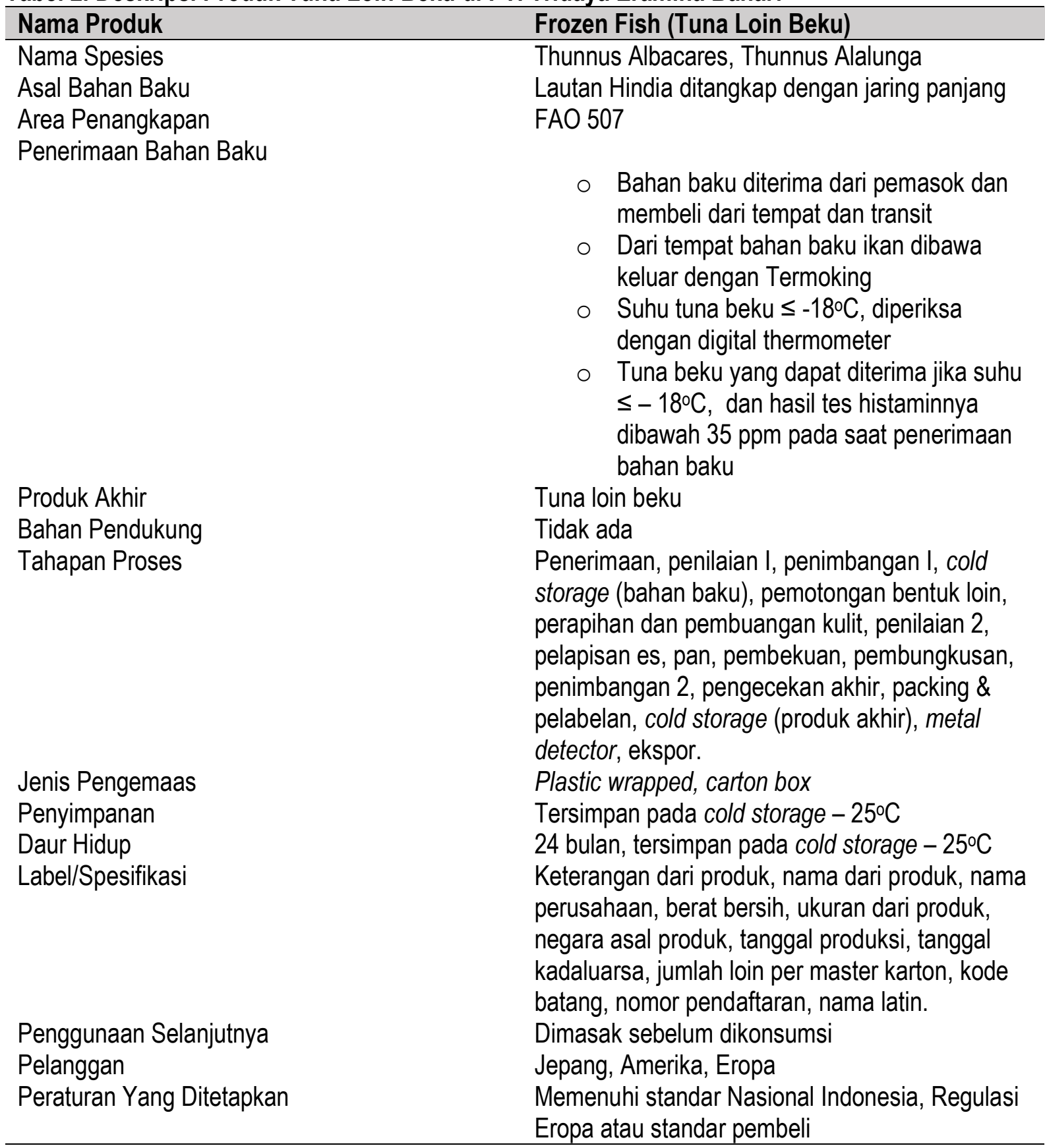


Deskripsi produk tuna loin beku di PT. Tridaya Eramina Bahari sudah sesuai dengan aturan BSN. BSN (2017) menyatakan bahwa suatu produk harus yang memuat informasi tentang nama produk, nama ilmiah, asal bahan baku, cara penerimaan, produk akhir, bahan tambahan, asal bahan tambahan, langkah proses, pengemasan, penyimpanan, masa simpan, label, cara penggunaan, petunjuk pelanggan, sistem penjualan produk hingga sampai ke pengguna atau para konsumen. Akses informasi dapat diperoleh dengan jelas dan dicantumkan dalam pengemas.

\section{Identifikasi Penggunaan}

Produk tuna loin beku ini merupakan produk yang dikonsumsi konsumen dalam bentuk olahan yang matang atau setengah matang, seperti konsep makanan jepang dengan mengkonsumsi produk tuna loin dalam keadaan segar, agar terjamin keamanan produk bagi semua target sasaran konsumen pada skala nasional maupun internasional. Identifikasi penggunaan yang dituju bertujuan untuk menentukan spesifikasi dan standar mutu produk yang diharapkan, sehingga diterapkannya HACCP dalam unit pengolahan tuna loin beku agar dapat menghindari dan mencegah bahaya-bahaya yang kemungkinan muncul yang dapat beresiko buruk terhadap konsumen.

\section{Penyusunan Diagram Alir Proses}

Diagram alir produk tuna loin beku disusun oleh tim HACCP untuk menggambarkan keseluruhan proses produksi mulai dari penerimaan bahan baku sampai pada proses pendistribusian. Diagram alir produk ini selain bermanfaat untuk membantu menyusun HACCP plan, diagram proses produk tuna loin beku juga berfungsi sebagai pedoman bagi instansi atau lembaga lainnya memahami tahapan proses identifikasi dan verifikasinya. Diagram alir pembekuan tuna loin di PT. Tridaya Eramina Bahari ditunjukkan pada Gambar 1.

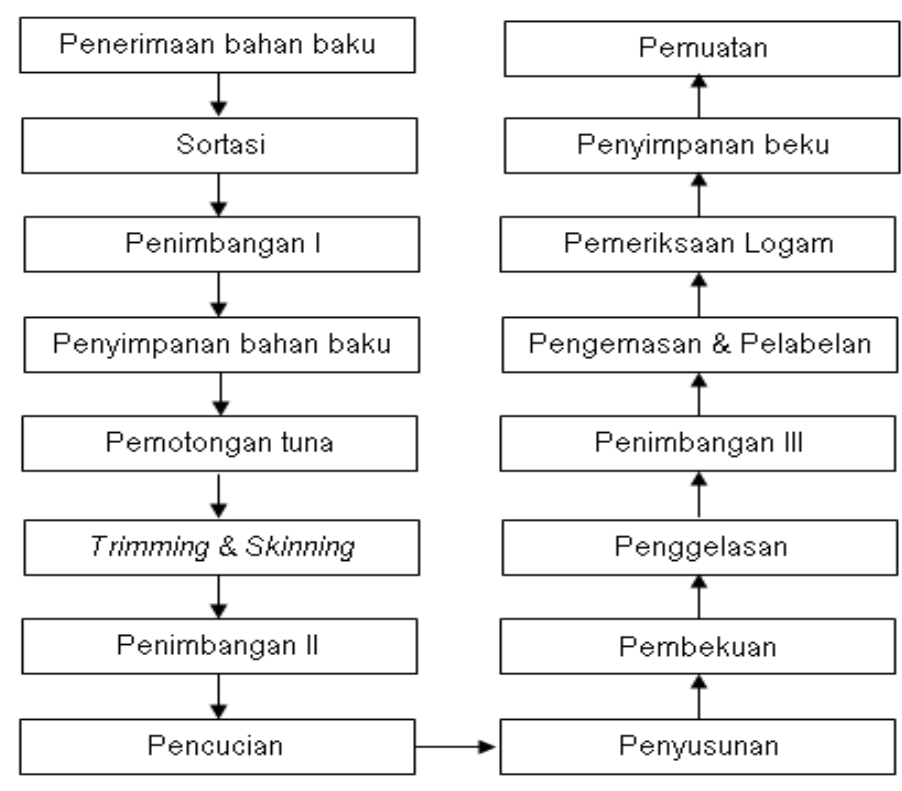

\section{Gambar 1. Diagram Alir Pembekuan Tuna Loin di PT. Tridaya Eramina Bahari}

\section{Pemeriksaan Diagram Alir Proses}

Verifikasi diagram alir dilakukan dengan cara mengamati kesesuaian antara prosedur pengolahan dalam dokumen dengan kondisi pengolahan di ruang produksi. Metode verifikasi diagram alir yang digunakan tim HACCP PT. Tridaya Eramina Bahari menggunakan sistem wawancara, observasi, dan pengujian laboratorium. Verifikasi diagram alir juga dilakukan jika terdapat perubahan tahap produksi atas permintaan konsumen atau alasan lainnya. 
6. Analisis Bahaya

Tahapan ini merupakan penerapan prinsip HACCP pertama di perusahaan. Pada setiap jenis bahaya yang terjadi dapat dijelaskan penyebabnya kemudian dipertimbangkan dengan tindakan pengendaliannya. Analisa bahaya dilakukan pada setiap tahapan proses produksi tuna loin beku. Analisa bahaya pada proses produksi tuna loin beku dilakukan untuk mengetahui terlebih dahulu faktor penyebab bahaya dan bahaya potensial yang ditimbulkan, kemudian mengkategorikan bahaya tersebut apakah termasuk biologi, kimia atau fisik dan menetapkan resiko atau signifikan bahaya yang teridentifikasi serta menetapkan tindakan pencegahan.

Bahaya fisik mencakup hama, kaca, logam, kayu, plastik, karet dan lainnya. Bahaya kimia termasuk bahan kimia pertanian seperti pestisida, bahan kimia pembersih dan sanitasi, cat, tinta, bahan pengawet, pewarna dan lain-lain. Sedangkan bahaya biologis mencakup bakteri, virus, fungi dan parasit (Soman \&Raman, 2016). Analisis bahaya ini diterapkan agar munculnya bahaya keamanan pangan dapat dicegah, dihilangkan atau dikurangi hingga batas aman yang ditetapkan.

\section{Penetapan Critical Control Point (CCP)}

Penetapan Critical Control Point (CCP) di PT. Tridaya Eramina Bahari berdasarkan pohon keputusan sesuai dengan prinsip kedua dalam sistem HACCP. Berdasarkan hasil analisis terhadap CCP pada setiap proses pengolahan tuna loin beku yang memiliki bahaya signifikan dapat dilihat pada Tabel 3.

Tabel 3. Identifikasi Titik Kendali Kritis di PT. Tridaya Eramina Bahari

\begin{tabular}{|c|c|c|c|c|c|c|}
\hline Tahapan Proses & $\begin{array}{c}\text { Bahaya Potensial } \\
\text { Nyata }\end{array}$ & $\begin{array}{l}\mathrm{P}^{*} \\
(\mathrm{Y} / \mathrm{T})\end{array}$ & $\begin{array}{l}\mathrm{P2}^{*} \\
(\mathrm{Y} / \mathrm{T})\end{array}$ & $\begin{array}{l}\text { P3* }^{*} \\
\text { (Y/T) }\end{array}$ & $\begin{array}{l}\mathrm{P} 4^{*} \\
(\mathrm{Y} / \mathrm{T})\end{array}$ & CCP \\
\hline $\begin{array}{l}\text { Penerimaan Bahan } \\
\text { Baku }\end{array}$ & Histamin & $\mathrm{Y}$ & $\mathrm{T}$ & $Y$ & $\mathrm{~T}$ & $\mathrm{CCP}$ \\
\hline $\begin{array}{l}\text { Pengemasan dan } \\
\text { Pelabelan }\end{array}$ & Kesalahan Label & $Y$ & $Y$ & - & - & $\mathrm{CCP}$ \\
\hline Pengecekan logam & Serpihan logam & Y & $Y$ & - & - & $\mathrm{CCP}$ \\
\hline
\end{tabular}

\section{Penetapan Batas Kritis Setiap CCP}

Titik kendali kritis (Critical Control Point) yaitu tahapan untuk pencegahan bahaya atau menghilangkan potensi bahaya tersebut sampai pada batas yang dapat diterima. Penentuan CCP ini berasal dari pohon penentuan keputusan. Pengambilan keputusan untuk penentuan CCP ini dilakukan dengan menganalisis semua lini tahapan proses, sehingga diketahui tingkat CCP tersebut (Hermansyah et al., 2013). Bahaya yang tidak terkontrol oleh adanya program persyaratan dasar berupa GMP dan SSOP dan memiliki signifikansi yang nyata dalam tahapan proses produksi dinyatakan dalam kelompok CCP. Tahapan batas kritis pada setiap CCP ditetapkan berdasarkan referensi dan standar teknis serta pengamatan pada unit produksi. Batas kritis menunjukkan perbedaan antara produk aman dan tidak aman, sehingga setiap CCP mudah teridentifikasi dan dapat dijaga oleh karyawan proses produksi. Batas kritis Batas kritis dari masing-masing CCP di PT. Tridaya Eramina Bahari ditetapkan seperti pada Tabel 4.

Tabel 4. Penetapan Batas Kritis Setiap CCP

\begin{tabular}{llll}
\hline CCP & & Bahaya Nyata & Batas Kritis \\
\hline $\begin{array}{l}\text { Penerimaan } \\
\text { baku }\end{array}$ & bahan & Pembentukan histamin & $\begin{array}{l}\text { Kandungan histamin > } \\
\text { Pengemasan }\end{array}$ \\
$\begin{array}{l}\text { Pelabelan } \\
\text { dan }\end{array}$ & Allergen & $\begin{array}{l}\text { Dicantumkan } \\
\text { keterangan allergen dan } \\
\end{array}$ \\
& & jenis ikan \\
\hline
\end{tabular}


Aurelia Journal, Vol. 2 (1): 53-62

\begin{tabular}{lll}
\hline CCP & Bahaya Nyata & Batas Kritis \\
\hline Pengecekan logam & Serpihan logam & \\
& & $-\mathrm{Fe}>3,0 \mathrm{~mm}$ \\
& $-\mathrm{Sus}>3,5 \mathrm{~mm}$ \\
& $-\mathrm{No} \mathrm{Fe}>3,5 \mathrm{~mm}$ \\
\hline
\end{tabular}

\section{Penetapan Tindakan Monitoring Setiap CCP}

Kegiatan yang dilakukan perusahaan pada tahap monitoring adalah memantau dan memeriksa tahapan penerimaan bahan baku, pengemasan dan pelabelan dan pengecekan logam. Prosedur pemantauan dilakukan dengan memeriksa suhu ikan dan melakukan pengujian kandungan histamin yang terdapat pada setiap bahan baku yang datang oleh staf Quality Control dan meminta surat hasil analisis laboratorium dari supplier yang menjelaskan bahan baku yang datang terbebas dari bakteri pathogen dan logam berat. Hafez (2018) menyatakan bahwa bakteri pembentuk histamine biasanya berasal dari air asin dan memiliki kemampuan tumbuh dan menghasilkan histamin pada berbagai suhu. Untuk mencegah kontaminasi dari bakteri maupun histamin perlu diperhatikan kondisi higienis yang baik terkait personil dan peralatan yang bersih sehingga terhindar dari masuknya spesies mikroba baru dan kontaminasi silang.

Tindakan monitoring yang dilakukan selanjutnya pada tahap pengemasan dan pelabelan. Prosedur pemantauan dilakukan dengan mengecek bahan pengemas dan label yang dilakukan oleh staf Quality Control dengan mengecek tata cara penyimpanan bahan pengemas dan tata cara pembuatan label produk yang sesuai dengan persyaratan label. Pemantauan pada proses metal detektor dilakukan dengan melakukan pengujian sensivitas mesin metal detektor setiap sebelum proses dan 30 menit sebelum digunakan oleh staf Quality Control.

\section{Menetapkan Tindakan Koreksi}

Tindakan koreksi merupakan pelaksanaan prinsip kelima dari sistem HACCP. Tindakan koreksi penting dikembangkan untuk menangani penyimpangan yang terjadi. Tindakan koreksi juga harus dilakukan ketika hasil pemantauan menunjukkan kehilangan kendali pada CCP. PT. Tridaya Eramina Bahari melakukan tindakan koreksi atas penyimpangan yang terjadi di perusahaan terhadap bahan baku adalah pengembalian kepada supplier. Tindakan koreksi terhadap tahap pengemasan dan pelabelan dengan mencantumkan allergen dan jenis ikan pada label kemasan. Adapun pada pengecekan logam yaitu tuna loin beku yang terdeteksi mengandung fragmen logam dipisahkan dan dibongkar selama sensitivitas alat detektor masih terjaga. Jika metal detector gagal mendeteksi keberadaan serpihan logam maka dilakukan kalibrasi atau perbaikan terhadap alat tersebut dengan cara memeriksa sensitivitas alat sehingga fragmen logam yang melewati alat tersebut dapat terdeteksi.

\section{Menetapkan Prosedur Verifikasi}

Tahapan ini merupakan prinsip HACCP ke 6 yang sangat penting untuk menentukan apakah sistem HACCP yang diterapkan bekerja secara efektif. Adapun metode untuk melakukan verifikasi adalah dengan melakukan pengecekan terhadap catatan dan dokumen-dokumen HACCP seperti catatan monitoring proses, monitoring CCP dan catatan-catatan lainnya.

Verifikasi dilakukan dengan melakukan audit internal yang terencana, analisis pasar, penelusuran kembali hasil produk jadi, bahan baku dan produk setengah jadi di laboratorium eksternal yang terakreditasi (Szyrocha\&Abbase, 2020). Prosedur verifikasi terhadap tahapan yang termasuk CCP yang dilakukan di PT. Tridaya Eramina Bahari adalah sebagai berikut:

a) Penerimaan bahan baku

Prosedur verifikasi yang diterapkan di PT. Tridaya Eramina Bahari yaitu pada penerimaan bahan baku dilakukan pengecekan catatan jumlah dan asal bahan baku, serta hasil uji kimia dan mikrobiologi bahan baku. 
Aurelia Journal, Vol. 2 (1): 53-62

b) Pengemasan dan pelabelan

Verifikasi pada tahap pengemasan dan pelabelan dilakukan pengecekan form material holding untuk mengecek penerimaan bahan pengemas.

c) Pengecekan logam

Verifikasi yang dilakukan pada tahapan pengecekan logam dengan melakukan pengecekan lembar monitoring pengecekan logam berat setiap hari dan dilakukan kalibrasi dan validasi alat setiap 1 tahun sekali oleh pihak perusahaan.

12. Penetapan Dokumentasi dan Pencatatan

Penetapan dokumentasi dan pencatatan merupakan prinsip HACCP ke tujuh yang diterapkan perusahaan. Dokumentasi dan pencatatan di PT. Tridaya Eramina Bahari antara lain dokumentasi tim HACCP, deskripsi produk, diagram proses, catatan monitoring semua tahapan proses mulai dari penerimaan bahan baku sampai penyimpanan produk akhir, catatan tindakan koreksi, catatan tindakan verifikasi, dan rekaman dari setiap tahapan yang dipantau sesuai dengan periode tertentu, data verifikasi dan hasil perbaikan pada setiap CCP atau setiap penyimpangan yang terjadi dan lain-lain

\section{Kesimpulan}

PT. Tridaya Eramina Bahari telah menerapkan sistem HACCP dalam menjaga keamanan produk tuna loin beku. Namun ada tahapan proses yang perlu diperhatikan sehingga mencegah munculnya bahaya keamanan pangan. Tahapan tersebut adalah penerimaan bahan baku, pengemasan dan pelabelan, serta pengecekan logam berat.

\section{DAFTAR PUSTAKA}

BSN. (2017). SNI-821-2017 Tata Cara Penggunaan Tanda SNI dan Tanda Kesesuaian Berbasis SNI. Badan Standar Nasional. Jakarta

Emborg, J, Laursen, G, \& Dalgaard, P. (2005). Significant histamine formation in tuna (Thunnus albacore) at $20 \mathrm{C}$ - effet of vacuum and modified atmosphere-packaging on psychrotolerant bacteria. Journal of Food Microbiology, 101(3), 263-279.

Firdaus, M. (2018). Profil perikanan tuna dan cakalang di Indonesia. Buletin IImiah "MARINA" Sosial Ekonomi Kelautan dan Perikanan, 4(1), 23-32.

Hafez, A.E.E., Darwish, W.S., El Bayomi R.M., \& El Nahal, S.M. (2018). Quality Indicators Of Some Frozen Fish And Fish Products Marketed In Sharkia Province, Egypt. 5th International Food Safety Conference, Damanhour University.

Hermansyah, M., Pratikto., R. Soenoko, \& N. W. Styanto. (2013). Hazard analysis critical control point (HACCP) produksi maltosa dengan pendekatan good manufacturing practice (GMP). Journal of Engineering \& Management in Industrial System, 1(1), 14-20.

Kementerian Kelautan dan Perikanan. (2015). Rencana Pengelolaan Perlkanan Tuna, Cakalang dan Tongkol. Direktorat Sumber daya Ikan Direktorat Jenderal Perlkanan Tangkap. KKP. Jakarta.

Oo, K.S, Than, S.S, \& Oo, T.H. (2019). A Model HACCP Plan for Fish Seasoning Powder Production. American Journal of Food Science and Technology. 7(6) : 200-204.

Pal, M., Aregawi, W.G., \& Singh, R.K. (2016). The role of Hazard Analysis Crit-ical Control Point in food safety. Beverage \& Food world, 43(4), 33-35.

Prayitno, A.D. \& Sigit, M.B. 2019. Penerapan 12 tahapan hazard analysis critical control point (HACCP) sebagai system keamanan pangan pada produk udang (panko ebi). Jurnal Teknologi \& Industri Hasil Pertanian, 24(2), 100-112. 
Soman R. \& Raman M. (2016). HACCP system -hazard analysis and risk assessment, based on ISO 22000:2005 methodology. Food Control.

Szyrocka, J.R. \& Abbase A.L. (2020). Quality management and safety of food in HACCP system aspect. Production Engineering Archives, 26(2), 50-53. 
